\title{
The 'bickerings' of the 'Mangungu Brethren': Talk, Tales and Rumour in Early New Zealand
}

ANGELA WANHALLA

On their arrival in the Bay of Islands in April 1822, New Zealand's first Wesleyan missionaries were surrounded by the sound of voices. There was much talk about the Anglican missionary Thomas Kendall, who had recently left his wife and family to co-habit with a chief's daughter. Reverend Samuel Leigh did not initially believe the reports, 'but from the first of our arriving onshore to this day it hath been sounding in our ears'. ${ }^{\text {. Cases of sexual }}$ scandal within the Church Missionary Society (CMS) and the Wesleyan Missionary Society (WMS) are productive sites for exploring the cultural work of talk, particularly the ways talk was structured and governed, and how words and speech could be mobilized against individuals. ${ }^{2}$ Thomas Kendall and William Yate, for instance, were the subject of gossip and rumour in the 1820 s and 1830s respectively. Both lost favour, and were dismissed from the CMS. ${ }^{3}$ William White (1794-1875), superintendent of the Hokianga mission (1830-36), was also dismissed from the New Zealand mission, but, unlike others in a similar situation, he returned to the colony as a settler. On his return, talk, in the form of what White described as 'telling tales', followed him during his life in Auckland and Northland.

White's fall from grace has been the focus of a lively scholarship concerned with his mission career. A standard account has emerged, that local traders conspired to eject White from the mission because he was successfully competing against them. ${ }^{4}$ In 1836 around 90 Europeans worked at Hokianga in the timber trade, and in order to protect Māori interests White used Māori labour on mission saw-pits, acting as their agent. Missionaries and merchants feared the increased influence this would give him. ${ }^{5}$ Mercantile men understood the value of talk, and exploited rumours in circulation since 1824 about White's morality to discredit him. As part of this project, depositions were gathered against him in late 1835, and more in April 1836. In July White left for Sydney, and then travelled to England to face a committee of his peers.

White's mission career ended at a committee held at Hatton Gardens, London, in February 1838 which investigated several charges against him. 
These included financial mismanagement, selling missionary land to his brother, Francis White, engaging in 'secular matters', namely the timber trade, and establishing a 'commercial mission'. He was also accused of intemperance, the physical abuse of Māori in public, and claiming fellow missionaries were conspiring against him. The investigating committee described his accounts as 'quite unintelligible' and the most incongruous they had ever seen. The sale of land to his brother was 'an unjustifiable and dishonourable transaction', while White's 'secular dealings with native and other merchants [went] beyond any necessity arising from his office as Superintendent of the Mission'. Probably most importantly to mission authorities, his entanglements in secular activities had endangered his reputation and that of the mission. Finally, the committee found his displays of temper and 'want of integrity' unbecoming to a Christian man. ${ }^{6}$

White was also charged with 'criminal conduct', based on the depositions of several Māori women, collected by the Additional British Resident Thomas McDonnell in 1835, and by White's fellow missionaries in April 1836, which detailed instances of sexual assault and allegations of rape. Eight depositions were placed before the committee, claiming that 'Mr White took improper liberties' and engaged in 'criminal intercourse', while also detailing the women's 'determined resistance'? White was dismissed from the society in 1838, but not for 'criminal conduct' against Māori women. Instead the committee found him guilty of engaging in trade, misuse of mission property, and displaying a want of integrity. On the charges of immorality, the committee deeply regretted being unable to prove them, but noted that White was unable 'to remove the deep stain which this cleaves to his character'. ${ }^{8}$

I am not interested in judging White's guilt or innocence. ${ }^{9}$ Instead, White's case highlights how certain forms of talk, notably rumour, accusation and testimony, operated within and across mission communities. In this essay I trace the role of talk in the career of William White. I look at how talk about White gained purchase in the 1830s, and played a part in his dismissal from the WMS. Unlike previous research on White, I do not end the story with his dismissal, or his life as a timber trader in Northland during the 1840s. Rather, I track the fate of White into the 1860s, using an 1862 court case to illuminate how the rumours of the 1830s retained cultural meaning in the 1860s. I demonstrate that paying attention to social practices like talk not only helps us to understand how relationships were forged, sustained or broke down, but also illuminates the structures and conventions that governed the oral world of missionaries..$^{10}$ In this context, where expertise in speech-making, public debate and preaching were valued, talk could also easily destroy a reputation. 


\section{Orality in the mission community}

Modes of talk can be sanctioned or informal, and both assist to establish and maintain social rules, protocols and customs, and to mark 'proper conduct' in the mission field. ${ }^{11}$ Ways of talking and what one talked about and to whom denoted social rank and status and marked a group as exclusive. In nineteenth-century British gentleman's clubs, patronized mainly by elite men, their oral world was defined around codes of honour, gentlemanly masculinity and appropriate behaviour. ${ }^{12}$ Similarly, a set of codes structured the ways missionaries talked to and talked about others: their talk, articulated in letters and journals, testifies to a world structured and mediated through sound, centred on conversation, preaching, judgements and arguments.

The oral world of missionaries is evident in their writing. In colonial life, letters, according to Taranaki settler Christopher Richmond, were a vital form of communication, an opportunity 'for real talk with my friends upon paper'. Letters, he continued, had an advantage over conversation in that one could 'read or skim. It is not like being talked to by an untiring talker' and having to listen politely. ${ }^{13}$ Written correspondence could be read at leisure, lingered over and discussed. While Richmond refers to the way private conversation was mediated through the written word, public and private talk within and across mission societies is revealed in the textual archives. Diaries, journals, and even public letters reveal private thoughts and reflective commentary. These writings also reveal the oral conventions of the community to which these men belonged. As Alan Atkinson has argued, the voices and sounds of the past are mediated through the written word. Even though writing 'makes no noise', it reveals modes of talk, registers of speech, the emotive power of words, the implications of talk, and the place of words 'within the fabric of conversation'. ${ }^{14}$ Exclamation marks and underlined sentences, for instance, work to emphasize points of significance. They are also markers of emotion, and invaluable evidence of the way sound was transferred onto paper.

White exemplifies the meeting of two oral worlds. Scholars of print culture have pointed to the relationship between the written word and orality. In assessing the impact of Christianity and literacy upon Māori society in the 1830s and 1840s, historians have turned towards Māori-language newspapers, highlighting the rich oral culture evident in the written word. ${ }^{15}$ In their composition and form, these writings were informed by the conventions and patterns of Māori speech-making, seen in the use of rhetoric, allusion and personification. ${ }^{16}$ In the newspapers, and more generally, Māori did not 'distance themselves from their words, but write as if they are standing to speak. ${ }^{17}$ Missionary writings also reveal their oral world, notably the forums where talk could take place and the protocols and rules that governed formal conversation. Formal talk in mission communities, like the WMS, 
was institutionalized within district meetings and these discussions were reproduced on paper.

Missionaries valued certain kinds of talk, especially preaching. Talk mattered in mission life; it was essential to the operation of mission, and could inspire conversion. Preaching the sermon was a highly public and performative act, and being skilled at it could enhance one's reputation. ${ }^{18}$ In his journal White commented on his colleagues' sermons. He described Nathaniel Turner's 'excellent sermon' as 'refreshing' in late February 1824, and his 7 March sermon as 'very appropriate and excellent'. ${ }^{19}$ Of his own sermon, in which he spoke with 'unusual freedom', White noted 'several found [it] improper'. ${ }^{20}$ For the WMS, restraint was a requirement of a good preacher. Their Māori audience regarded public oratory in a different light, valuing gesticulation, posture and passion. ${ }^{21}$ While White was criticized for his manner of preaching, his spontaneity helped him to stand out in the Māori oral world.

Missionaries in early New Zealand valued co-workers with linguistic skills. Language acquisition was an essential skill, but command of the words and knowledge of their cultural importance was vital in gaining the respect of a Māori audience. This was an oral culture in which 'a person's reputation could be marred or enhanced depending on his command of the spoken word'. ${ }^{22}$ White possessed some key requirements of a successful orator in whaikōrero (formal speech-making), including 'personal qualities, mana and charisma'. ${ }^{23}$ All of White's colleagues, who also comprised the bulk of his detractors, generally agreed that his superior linguistic abilities helped him capture a significant following amongst Māori. In December 1834, John Whiteley claimed White's 'knowledge of the language and his influence over the natives is of no ordinary character and if these are lost to the mission they will be a loss indeed'. ${ }^{24}$ James Buller arrived at Mangungu in May 1836. He immediately noticed White's skills, writing in his journal that 'It is much to be regretted that a man possessing good natural abilities as he does, and eminently qualified for the Mission work, so far as talents are concerned, should by his improper conduct render it necessary for him to be withdrawn and undoubtedly expelled once he gets to England'. ${ }^{25}$

Despite his obvious talent, White was the subject of less favourable discussion in mission communities from the late 1820s. In his modes of talk, behaviour and temperament White did not fit the requirements of an ideal Wesleyan missionary. He was volatile rather than calm, he was not systematic in his record-keeping or his management of the mission property, and he seemed to prioritize secular concerns over faith. White also failed to keep adequate minutes of district meetings, seemed to have no plans for the out-stations, was generally undisciplined and unable to act in a circumspect manner. Acrimonious working relationships marked the Hokianga mission, 
because White wanted, stated Whiteley, 'servile and implicit obedience'. ${ }^{26}$ In contrast, John Whiteley was the model missionary: a 'steady, docile, pious young man'. ${ }^{27}$ One's manner of talking shaped the wider reputation of the entire mission community. Henry Williams contrasted the conduct and conversation of White and the WMS with that of the CMS: 'quietness will be our safest conduct, and silence our best communication. They are full of bombast and noise. ${ }^{28}$

\section{Revelations and accusations: governing talk}

There was a place and a process for airing views and grievances. It was at special district meetings that a full and frank discussion of the moral character and behaviour of missionaries took place. District meetings were a routine part of WMS governance: when to pass on information mattered in the rituals of honour embedded in missionary societies. At district meetings applications for promotion were discussed openly. White, for instance, did not support a recommendation that James Stack become a Wesleyan missionary. ${ }^{29}$ At the April 1831 meeting the Reverend John Hobbs and Stack publicly charged White with being 'habitually angry', being involved in and causing intertribal violence and being intemperate. ${ }^{30}$

One could also be censured for talking out of turn. Like the clubmen of late nineteenth-century Britain, revealing matters of a private nature went against the interests of the individual's character and public standing, but, for the mission, it also brought it into disrepute. ${ }^{31}$ When James Watkin fell from grace in Tonga, Hobbs, also stationed there, "was distressed and that most deeply: indeed, it made me quite ill. It now became a question with me, what I ought to do. Here I remembered that I was under the strongest censure of the Committee, for having written about my former Superintendent Mr White and my soul was distressed. ${ }^{32}$

In order for talk to gain purchase, it required people to listen. Hobbs failed in 1831 to get mission authorities to take his accusations seriously. White was a figure of authority who commanded a significant following amongst Hokianga Māori. White was also adept at using the written word to defend his character, and to point out that those who listened to rumour were not to be trusted. In August 1831, Hobbs and Stack appealed to the CMS to support the charges. In response, White denigrated their reputation: 'The Church Missionaries have always had an open ear to the tales and tattling of my Brethren which has had a most injurious effect and tended more than anything else to alienate our affections from each other. Against this I have cautioned the Church Missionaries. But they have thought it their duty to listen to the tales which my Brethren have to tell.' ${ }^{33}$

Eventually, the persistence and volume of talk about White's leadership of the mission, as well as his character, forced authorities to take notice, 
and resulted in several investigations, the first by Sydney-based Joseph Orton in 1833. Orton found that mercantile concerns outweighed religious ones at White's station, and that personality clashes and 'bickerings' had reduced the effect of the mission, while there was a 'want of system and regularity' in the management of the station. ${ }^{34}$ The station gained a reputation as a mercantile establishment and this view became entrenched over time. A year later, Orton found a mission station so entrenched in trade that he feared it would bring the society into disrepute. ${ }^{35}$ Thomas McDonnell, the Additional British Resident, collated depositions against White in late 1835, and placed him on trial before a public meeting of Māori and settlers at the Horeke shipyard in January 1836. White was found guilty. Soon afterwards, Nathaniel Turner investigated White in April 1836, calling a district meeting. ${ }^{36}$ Special district meetings were a place to air grievances, but also to support colleagues. Turner wanted to assist White 'to triumph over his accuser [McDonnell] not place him on public trial'. ${ }^{37}$

Certain kinds of talk emanating from particular groups were valued above that of others. In mission journals, diaries and letters, judgements are passed on the manners and behaviour of colleagues based on their mode of talking, particularly one's ability as a preacher. Māori, however, commonly 'harangue' in missionary writings, and their talk is often discarded or treated as untrustworthy. But the talk of baptized Māori was different: it was civilized in manner, less emotional, contained, controlled and fitted the kinds of talk that missionaries understood. These distinctions are obvious in the way Māori testimony is valued or discarded in the investigations into the conduct of William Yate and White.

Yate and White make an interesting pair: the former an educated and intellectual young man, widely viewed as gifted, the latter the rough and physical tradesman with a fiery temper. Yate and White share much in common: they were stubborn, strong-willed and self-righteous. They were also great self-promoters. White's many letters defending his actions were written in a way to elevate his role and to denigrate and accuse others, while Yate's 1835 book An Account of New Zealand, written and published while he was in England, was the first account of the history of the CMS mission to New Zealand, and he placed himself in a central role. Their careers parallel each other, and their fate was similar, with White dismissed from the mission in 1838 and Yate in 1837. In the same year, they were both being investigated for sexual misconduct, a fact noted by the WMS printer William Woon. It was a situation, he wrote, that must be 'unparalleled in the history of the Missionaries. The cause has received a wound in the two Missions which will not be soon healed'..$^{38}$

White and Yate did not get along with each other. Gossip about Yate circulated amongst New Zealand mission communities from 1831, and White 
was prominent in spreading the rumours..$^{39}$ By 1836 , Yate had been accused of improper sexual contact with Māori boys. Initially no one believed the rumours about Yate: 'the Missionaries so decidedly refuse in general to lend any ear to Native Reports, and what little has been said about Mr Y was so sharply checked as being scandalous and false, that the Natives would find little encouragement to make any further expose, especially with the sense of shame that some of them possess' ${ }^{40}$ Similarly, the sexual accusations against White were not believed. McDonnell's claim was thought to have arisen out of personal malice and jealousy of White's influence over local Māori. Eliza, William's wife, thought this was the case. In December 1835 she described McDonnell as 'a bitter foe. He is determined, he says, to exert his utmost to get us away from this island, and is exciting some wicked men and deceitful Natives to unite with him' creating slanders and 'lying intrigues' ${ }^{41}$ Turner initially believed McDonnell's claims were false, but charges of a similar nature arose independently of McDonnell and entirely unsought, 'that we cannot but believe them true'. ${ }^{42}$

In McDonnell's investigation Māori testimony was marshalled against White. Brethren had been willing to support White, but with the unsolicited testimony of Māori women, White was no longer deserving of that protection. Why did 'native' testimony suddenly matter, when in general it was often disregarded and cast as gossip? Talk gained authority and reliability through repetition. In addition to this, testimony, and its reliability, were contingent on proximity, as well as the civilized status of the individual. Māori talk also gained authority and evidential value in part because the WMS were willing to listen. The testimonies given to Turner in April 1836 included a claim of sexual assault by White on the wife of a baptized chief, and a deposition from a Māori man in White's service, claiming White 'had connexion' with his wife. The fact that these testimonies arose outside the sphere of McDonnell's influence convinced Turner of their value, not only as testimony but also as evidence. In their independence lay their reliability, and in the 'civilized voices' of baptized Māori resided their truthfulness. When considering how to treat Māori talk as testimony, the WMS looked to the example of the CMS, who were in the midst of gathering evidence against Yate. William Woon wrote, in his characteristically emphatic fashion:

A few weeks ago while the brethren and myself were employed making out the District accounts, one and another unsolicited by us preferred the most awful charges against him. At the same time the Church Missionaries at Waimate were employed taking down disgusting charges preferred against the Rev. W. Yate and received them as truth not doubting for a moment the integrity of the natives who had long made a profession of Christianity. I first said to Bro. F. Whiteley and then to Bro. Turner that if the Church Missionaries received the Native 
statements against Mr. Y. we ought to do so in reference to $\mathrm{Mr} \mathrm{W}$. and we ought to also call the leaders together and consult them on those charges, which was accordingly done. ${ }^{43}$

In consulting with Māori, and making use of the protocols and conventions that structured the Māori oral world, the WMS were acknowledging White's status, and also signalling that taking action against White would place the mission in a precarious position. Without Māori acceptance of the testimony, it was politically dangerous for the WMS to believe the rumours.

\section{Rumour and its consequences}

Failing to demonstrate proper and moral behaviour had social consequences in the form of ongoing rumours. James Watkin was sent to Waikouaiti by the WMS in 1840 for an indiscretion in Tonga. He was a self-described man 'with a broken spirit' in September 1840, and 'despised by himself and by others and deservedly so'. ${ }^{44}$ Less than a year later, in May 1841, he requested removal from the New Zealand circuit. ${ }^{45}$ Watkin faced competition for souls from the Catholic mission, who used his past indiscretion to shame him amongst the whalers, whom he despised, and Māori. He had hoped he was 'going to a corner of the world in which I should go unnoticed and unknown, but I have been disappointed in this, and it is well known the Papists are not generous enemies'. ${ }^{46}$ Similarly, White was shadowed by rumour about his past behaviour on his return to New Zealand. As Ann Laura Stoler has remarked, rumour is a 'charged cultural space', but rumour was not stationary; it travelled, shadowing people wherever they went. ${ }^{47}$

It is through talk, as revealed in the private writings of settlers, as well as the public and private writings of missionaries and in newspaper reports, that the post-1840 life and career of William White can be recovered. The archive on White is fragmentary, not least because White left behind few personal writings. Instead, what exists is on paper is simply talk, much of which engaged in rumour. After his return to New Zealand in 1839, rumoured sightings, stories of arguments and physical fights, claims that he was publicly accused by Māori, and talk of raiding parties enacted against him by Māori circulated amongst WMS missionaries and within settler society, and served to reinforce widely held notions of his guilt.

White's return to the timber business encouraged the continuation of rumour amongst Hokianga settlers, and reprisals from his competitors. ${ }^{48}$ He settled into the timber trade at Kaipara, returning to the business that had generated disapproval amongst the missionaries and anxiety amongst Hokianga traders. While living at the Hokianga in 1840, near his former mission station, his timber business was 'robbed' by nine local settlers. ${ }^{49}$ That same year Woon reported: 'disgusting stories are afloat again about a certain person once connected with this Mission from his illicit intercourse 
with females - at Kaipara, and the people in general appear to know the man'. ${ }^{50}$ By 1842 White had established a saw-pit near his former mission at Mata Point and laid claim to thousands of acres of land purchased while he was with the mission. ${ }^{51}$

While working in the Hokianga White continued to preach to Māori without the sanction or approval of the WMS, much to the annoyance of his former colleagues. White understood the value of public speech amongst Māori and it was a mode of talk in which he was expert. He utilized practices of public debate and discussion common in the Māori oral world to call a public meeting at Mangungu in 1839, on mission land, 'to investigate the conduct of Messrs Turner, Whiteley, Wallis and Woon for irreparably ruining his character'. ${ }^{52}$ Unhappily for White, Māori also made use of public forums to voice their disapproval of his alleged continued mistreatment of Māori women. Again, White utilized Māori protocols and forums to call a public meeting to investigate the charges, at which 'he met the woman face to face and from beginning to end denied, while she positively declared his connexion with her, stating all the circumstances. The greater part of the natives present considered him guilty, but some were of a different opinion. ${ }^{53}$ In this instance, adeptness in public speech-making, in conjunction with charisma, and a command of the Māori language could work to persuade.

Just as White's past followed him wherever he went, the WMS was also constantly shadowed by talk about him. White became an excuse for the failure of the Wesleyan mission to Māori. Māori talk about White was employed by his former colleagues as evidence that his conduct had lost them converts, undermined the mission and provided a poor model for Māori, who were falling into immorality. ${ }^{54}$ Indeed, 'Mr Hobbs our oldest Missy. declares that such complaints did not exist formerly. And the natives up to this day talk about Ws illicit intercourse with females. ${ }^{55}$ In February 1845 Hobbs lamented that

such has been the constancy of conversations before children of all ages respecting these disgusting sins [of White] that sorrow has filled my heart. Nothing but conversations about fornication and adultery occupied the young and foolish for weeks, and many of them ventured to broach these filthy subjects even to the children of the Missionaries themselves as they passed our houses. ${ }^{56}$

Morality tales were told in reports to London authorities. Baptised chiefs, formerly models of Christianity, were falling back into 'savage' practices. Hobbs claimed the young chief who went on one of the raiding parties told White: 'I am now no longer religious; but don't reproach me. I have not done as you have. You have fallen from the throne. You have fallen from teaching. You have fallen into adultery and you have taught others by your example. ${ }^{57}$ 
When White returned to New Zealand he came back to a society where rumour and accusation found voice in colonial newspapers. ${ }^{58}$ In the early 1850s, when White was living there, Auckland was a community of 4500 people dominated by the military and officials. ${ }^{59}$ At that time, its two newspapers, the New Zealander and the Daily Southern Cross, 'afford abundant facilities for those who love to see themselves in print. For real grievances or for wounded vanity, for disappointed ambition and for injured innocence, a vacant column is ever ready. ${ }^{60}$ Auckland's settler community used the newspapers to give voice to grievances, and to make personal attacks on enemies. It is in the colonial newspapers that White comes to the attention of a wider public. In July 1862 an assault case was heard before the police court, concerning an altercation that had taken place in the law library during the hearing of an arbitration case. At the police court, Thomas Beckham, the resident magistrate, admitted the assault was not very serious in nature, but it was nonetheless 'a very disagreeable offence'. ${ }^{61}$ The offender had apologized, but the plaintiff wanted the case heard before the public.

On Wednesday 1 July, an arbitration case between Māori landowners and William White, agent for the trustees, took place in the law library. The solicitors were Mr Wynn and Mr Beveridge. C.O. Davis acted as interpreter. During the process of arbitration, White and Davis came into conflict over 'talk', which few of the Pākehā witnesses understood 'as they conversed in the Maori tongue'. White had asked Davis to translate a word to all assembled, as did Mr Wynn, who explained:

Mr White was at that time sitting on the opposite side of the table to $\mathrm{Mr}$ Davis, and in consequence of something more being said, $\mathrm{Mr}$ White got up and pushed Mr Davis roughly by the shoulders, at the same time requesting him to interpret the word. Mr Davis told Mr White not to repeat the insult or he would bring him before the court, when Mr White advanced another step and spat in Mr Davis's face.

What word could have sparked such behaviour? Throughout the case White had charged Davis with giving 'false interpretations'. Countering, Davis responded using a word 'which [stated a witness to the police court] could be used very offensively, and might be taken to mean a viper, or crawler, or it could be construed to mean a humbug. Something was said about its being used in a joke.' The word was ngārara. In his evidence before the police court Davis explained that it

means an insect, a reptile. The worst construction that can be put on the word is reptile, and the least an insect. The reptile, in Maori, is a lizard. The word is used offensively and jokingly. I said the word in speaking to a native. I said 'Ngarara accuses me of false interpretation.' I used it to express my displeasure at the defendant's accusations against me. 
Mr Munro, who described himself as 'well acquainted with the Māori language and the Māori customs', explained to those present in the police court that ngārara 'is used by the natives literally as an insect or reptile; and figuratively for anything either loathed or feared. It may be used jokingly; but I have never heard it used so.' Beveridge 'formed the impression from Mr Davis's conduct that he intended to give a most deliberate insult to $\mathrm{Mr}$ White', and although he did not understand the conversation 'I conceived this opinion from Mr Davis's manner'. In the end, actions mattered more than words. White was found guilty of assault, and Davis protected for his insult.

Ngārara could be used as a descriptor or as a metaphor for evil. In settler newspapers during the 1860 s the word was a part of public vocabulary, and its variety of meanings understood. In June 1866, Māori fear of lizards was described as a superstition, an 'incarnation of the deity powerful for evil'. ${ }^{62}$ In other newspaper reports readers were informed that ngārara could take the form of a spirit, inhabit a body and cause illness or death. ${ }^{63}$ Testimony from Pākehā witnesses in the 1862 case also demonstrates some knowledge of the word, in both its literal and metaphorical sense. That the word was intended as an insult was also clear in White's reaction. Even though he downplayed the metaphorical meaning of the term, Davis sought to use the colonial newspapers to serve a personal agenda by gaining a wider audience for this insult, an audience familiar with White's associations with the Hokianga.

Knowledge of Davis's connection to the WMS and the Hokianga deepens our understanding of why White was labelled a ngārara. Charles Oliver Bond Davis had been connected with the Wesleyan mission at Hokianga since 1831, where he had acted as tutor to the children of William Woon. By 1842 he was an interpreter and clerk in the Auckland office of the Aborigines Protectorate, retaining the same position when the native secretary's department was established. He was also involved in the publication of the Māori-language newspaper Te Karere Maori. ${ }^{64}$ Davis was well acquainted with the dramas of the 1830s and with all the key protagonists, particularly the Woon family. Woon was one of the 'Mangungu Brethren' who was most aggrieved by White's actions in 1836 . Woon had initially supported White. ${ }^{65}$ He had gathered testimonials from settlers living along the Hokianga River, in addition to one he wrote on White's request. On receiving the unsolicited testimony from Māori women, Woon wrote anxious letters to the WMS authorities explaining his past support, and his generous review of White's character. ${ }^{66}$ By January 1837 Woon was convinced of White's guilt, and from that date was his most vocal critic both in conversation and on paper. ${ }^{67}$

Davis spoke for Woon in his use of ngārara, but he also appealed to another audience, the Māori men in court. In describing White as a ngārara, 
Davis evoked its metaphorical and spiritual associations with evil. In The Art of Conversation, cultural historian Peter Burke sees the social significance of forms of language, and genres of speech, in what they can reveal about the extent to which people and communities are interconnected. Burke describes the insult as a 'dramatic illustration of the active force of language' used to 'annihilate the reputation of the victims, to bring about their social destruction'. ${ }^{68}$ Davis reminded the Māori audience that this was a man not to be trusted, and, most importantly, that he was a man to be feared.

\section{'Telling tales'}

We will never know if White was guilty of sexual misconduct, but what talk about him reveals is the divisiveness within the WMS ranks, as individuals fought for control of the mission and sought to elevate themselves over others. In the end, rumours of misconduct were entangled within a competition for authority. Talk was one of the vital ways in which one's reputation could be undermined amongst settlers and missionary societies. Indeed, Samuel Leigh warned Marsden about talk in 1822. Having witnessed the reaction to Kendall's actions, Leigh felt the 'discontent of your missionaries does not arise from what they meet with from the natives but from what is among themselves' ${ }^{69}$

William White disappears from view after 1862, but he did have his supporters. At his death in 1875, the Auckland Star described him as 'one who had battled and struggled in this country for some forty-five years, and of which struggles persons recently arrived in New Zealand can have no adequate idea'. ${ }^{70}$ One of those struggles was with how to contain the power of talk, which he recognized in 1839 as having ruined his character. White used talk to regain his status amongst Māori in the Hokianga, specifically through public debate and formal speech-making, as well as unsanctioned preaching. Concerns about White's behaviour and the continuation of talk about him, which is so voluble and extensive in letters to WMS authorities, signals White was a man to be feared. Here was an individual who understood Māori oral culture and how to command respect in that world. Indeed, White proved he was adept and proficient at talk. More importantly, he understood the cultural value and the significance of talk amongst Māori, where one's abilities were linked to power, status and authority.

White happily engaged in public debate within the oral conventions of whaikōrero because he was highly skilled at it. His ability to persuade helped resurrect his reputation amongst some Māori. The practice of using newspapers to attack an individual's politics, standing and reputation, however, was outside White's control. In colonial newspapers talk of all kinds was printed with alacrity, giving a wider readership access to gossip, rumour and accusation than ever before. In the face of a public colonial 
print culture centred on newspapers, White found it much harder to protect and repair his reputation.

The research for this article was supported by a Royal Society of New Zealand grant from the Marsden Fund. In addition to generous financial support, this article has been much improved by the careful and considered comments of Mark Seymour, Tony Ballantyne and Lachy Paterson.

1 Leigh to Marsden, 4 April 1822, Letters to Samuel Marsden, box 53, PPHR, Methodist Church of New Zealand Archives (MCNZ), Christchurch.

2 On the relationship between rumour, scandal and sexual behaviour see Adele Perry, 'The Autocracy of Love and Legitimacy of Empire: Intimacy, Power and Scandal in Nineteenth Century Metlakahtlah', Gender \& History, 16, 2 (2004), pp.261-88. Kirsten McKenzie explores the imperial and colonial implications of talk in Scandal in the Colonies: Sydney and Capetown, 1820-1850, Melbourne, 2005. On scandal in the New Zealand mission see Angela Wanhalla, “"The Natives Uncivilize Me”: Missionaries and Interracial Intimacy in Early New Zealand', in Patricia Grimshaw and Andrew May, eds, Missionaries, Indigenous Peoples and Cultural Exchange, Eastbourne, 2010, pp.24-36.

3 On Kendall see Judith Binney, The Legacy of Guilt: A Life of Thomas Kendall, 2nd edn, Wellington, 2005. For a discussion of the Yate case see Binney, 'Whatever Happened to Poor Mr Yate?', New Zealand Journal of History, 9, 2 (1975), pp.111-25 and Chris Brickell, Mates and Lovers: A History of Gay New Zealand, Auckland, 2008, ch.1.

4 Murray B. Gittos, Mana at Mangungu: A Biography of William White, 1794-1875, Wesleyan Missionary at Whangaroa and Hokianga, Auckland, 1982; Gittos, Give us a Pakeha, Auckland, 1997; Gittos, 'White, William', Dictionary of New Zealand Biography. Te Ara - the Encyclopedia of New Zealand, updated 1-Sep-10, http://www.TeAra.govt.nz /en/biographies/1w19/1; George I. Laurenson, Te Hahi Weteriana: Three Half Centuries of the Methodist Maori Mission, 1822-1972, Auckland, 1972, pp.29-30, 42-43; J.M.R. Owens, 'The Wesleyan Missionaries to New Zealand before 1840', Journal of Religious History, 7, 4 (1973), pp.324-41.

5 Megan Hutching, Over the Wide and Trackless Sea: The Pioneer Women and Girls of New Zealand, Auckland, 2008, p.48.

6 General Report of a Committee appointed by the Conference of 1837 to examine charges alleged against the Rev. William White, 26 February 1838-8 March 1838, Wesleyan Society Minutes, 1821-67, qMS-2179, Alexander Turnbull Library (ATL), Wellington. Hereafter referred to as General Report.

7 Ibid.

8 Ibid., 8 March 1838.

9 Raymond Shirritt-Beaumont, 'The Rossville Scandal, 1846: James Evans, the Cree, and a Mission on Trial', MA thesis, University of Manitoba/University of Winnipeg, 2001 examines a similar case at Manitoba. Like White, the Methodist missionary James Evans was the subject of rumour, which had circulated in the community for weeks, before a subordinate, William Mason, conducted an investigation into allegations of sexual misconduct. Like White, Evans and Mason had a difficult working relationship.

10 Tony Ballantyne, Talking, Listening, Writing, Reading: Communication and Colonisation, Allan Martin Lecture, Canberra, 2009, p.10.

11 Amy Milne-Smith, 'Club Talk: Gossip, Masculinity and Oral Communities in Late Nineteenth-Century London', Gender \& History, 21, 1 (April 2009), p.86.

12 Ibid., p.87. 


\section{Journal of New Zealand Studies}

13 Richmond to Harriet Gore-Browne, 8 November 1863, in Guy H. Scholefield, ed., The Richmond-Atkinson Papers Vol II, Wellington, 1960, p.72.

14 Alan Atkinson, The Commonwealth of Speech: An Argument About Australia's Past, Present and Future, Melbourne, 2002, pp.xiii, 42.

15 The most important study of the Māori-language newspapers is by Lachy Paterson. See his book Colonial Discourses: Niupepa Māori, 1855-1863, Dunedin, 2006.

16 Timoti Karetu, 'Maori Print Culture: The Newspapers', in Jenifer Curnow, Ngapare Hopa and Jane McRae, eds, Rere Atu, Taku Manu! Discovering History, Language and Politics in the Maori-Language Newspapers, Auckland, 2002, p.1; Jane McRae, "'E manu, tena koe!" "O bird, greetings to you": The Oral Tradition in Newspaper Writing', in Curnow et al., p.42.

17 Lyndsay Head, 'Kupu Pai, Kupu Kino: Good and Bad Words in Maori Political Writing', in Curnow et al., p.135.

18 Ballantyne, Talking, Listening, Writing, Reading, p.19. On speeches as public performance see Ken Inglis, Speechmaking in Australian History, Allan Martin lecture, Canberra, 2007 and Alan Atkinson, The Europeans in Australia: A History, vol. 1, Melbourne, 1997.

19 Entries of 26 February and 7 March 1824, William White Diary, 16 May 1823-21 September 1835, Series 2/1, MET 012, Kinder Library, St John's College, Auckland.

20 Ibid., 6 July 1824.

21 See Poia Rewi, Whaikōrero: The World of Māori Oratory, Auckland, 2010. Also see Anne Salmond, Hui: A Study of Maori Ceremonial Gatherings, Auckland, 1985.

22 Karetu, p.11.

23 Rewi, p.78.

24 Whiteley to Beecham, 3 December 1834, Whiteley Letters, folder 46, Wesleyan Mission Society (WMS) Papers, MCNZ. Also see Woon to Beecham, 4 November 1835, and Woon to Beecham, 26 April 1836, Woon Letters, vol. 1, folder 49, WMS Papers, MCNZ. Also see Laurenson, p.30.

25 Entry for 29 July 1836, Extracts from the Journal of James Buller, MS-0045/B, Hocken Collections (HC), Dunedin.

26 Whiteley to Beecham, 3 December 1834, Whiteley Letters, WMS Papers.

27 Orton to secretaries, 19 September 1834, Orton Letters, folder 38, WMS Papers.

286 September 1834, in Lawrence Rogers, ed., The Early Journals of Henry Williams, Senior Missionary in New Zealand of the Church Missionary Society, 1826-40, Christchurch, 1961, p.390.

29 White to Briggs, 25 February 1831, White Letters, folder 47, WMS Papers.

30 White to general secretaries, 27 April 1831, White Letters, WMS Papers.

31 Milne-Smith, p.96.

32 Hobbs to Beecham, 23 July 1838, Hobbs Letters, WMS Papers.

33 White to secretaries, 30 August 1831, White Letters, WMS Papers.

34 Orton to Rev. Watson, 3 June 1833; Orton to secretary, 19 September 1833, and Orton to White, [?] June 1833, Orton Letters, WMS Papers.

35 Orton to Briggs, 28 June 1834, Orton Letters, WMS Papers.

36 Turner to secretaries, 21 September 1836, Turner Letters, folder 42, WMS Papers.

37 Turner to Bunting, 16 November 1836, Turner Letters, WMS Papers.

38 Woon to Rev. Hoole, 29 April 1837, Woon Letters, WMS Papers. 
39 See Hobbs and Stack to secretaries, 22 February 1831, Hobbs Letters, WMS Papers. On his difficulties with Yate, see White to secretary, 30 August 1831, White Letters, WMS Papers.

40 Wade to Coates, 28 September 1836, Missionary Letters, part 1, letters 1-25, PC-0306/001 (HC). For a recent discussion of shame in New Zealand see Barbara Brookes, 'Shame and its Histories in the Twentieth Century', Journal of New Zealand Studies, 2010, pp.27-54.

4129 December 1835, Journal of Eliza White, Ms-Papers-8163-2 (ATL).

42 Turner to Bunting, 16 November 1836, Turner Letters, WMS Papers.

43 Woon to Beecham, 26 April 1836, p.2, Woon Letters, WMS Papers. On the reliability of 'native testimony' see, Wade to Coates, 28 September 1836, Missionary Letters, part, letters, 1-25, PC-0306/001 (HC), where Wade states 'It is no use for Mr Y to say that native testimony is not to be depended on. Most of the young men who have been examined are trustworthy baptized natives who themselves were drawn in by the wretched man's persuasions and rewards, without being conscious of the detestable nature of the crime into which he was leading them'.

44 Watkin to secretaries, 15 September 1840, Watkin Letters, folder 48, WMS Papers.

45 Watkin to general secretaries, 8 May 1841, Watkin Letters, WMS Papers.

46 Ibid.

47 Ann Laura Stoler, "In Cold Blood": Hierarchies of Credibility and the Politics of Colonial Narratives', Representations, 37 (Winter 1992), pp.151-89.

48 Webster to Russell, 2 February 1848, in Letters, Webster to Russell, 1848-1850, NZMS 4/19, Special Collections, Auckland City Library (ACL), Auckland. Also see John Webster Diary, 17 January 1847, NZMS 116, 117, Special Collections, ACL.

49 White to Shortland, 30 June 1840, IA/1, 2/1840/227, Archives New Zealand, Wellington.

50 Woon to secretaries, 4 February 1840, Woon Letters, WMS Papers.

51 Woon to general secretaries, 14 September 1842, Woon Letters, WMS Papers.

52 Woon to Beecham, 8 February 1839, Woon Letters, WMS Papers. Laurenson claims White's occupation of mission land, and his involvement in preaching, were part of a deliberate plan to discredit the WMS: Laurenson, p.56.

53 Woon to general secretaries, 28 November 1844, Woon Letters, WMS Papers. Plunder was also enacted in response to White's treatment of Māori women in 1845: Hobbs to secretaries, 5 March 1845, Hobbs Letters, WMS Papers.

54 Woon to general secretaries, 28 November 1844, Woon Letters, WMS Papers. John Hobbs wrote to the secretaries on 25 February 1845, claiming 'such has been the constant repetition of reports from the natives respecting his illicit intercourse with the native females, that our cause has never been free from its deadly influence': Hobbs Letters, WMS Papers.

55 Woon to general secretaries, 8 April 1840, Woon Letters, WMS Papers.

56 Hobbs to secretaries, 25 February 1845, Hobbs Letters, WMS Papers.

57 Hobbs to secretaries, 5 March 1845, Hobbs Letters, WMS Papers.

58 Tony Ballantyne, 'The State, Politics and Power, 1769-1893', in Giselle Byrnes, ed., The New Oxford History of New Zealand, South Melbourne, 2009, p.109.

59 William Swainson, Auckland, the Capital of New Zealand and the Country Adjacent: Including Some Account of the Gold Discovery in New Zealand, London, 1853, pp.65-66. 


\section{Journal of New Zealand Studies}

60 Swainson, p.67.

61 Daily Southern Cross (DSC) (Auckland), 5 July 1862, p.3.

62 DSC, 19 June 1866, p.3.

63 'Makutu,' Wellington Independent, 8 November 1862, p.3. 'An effort to abolish the rite of tapu', Lyttelton Times, 15 August 1857, p.3. For a recent examination of mākutu see Lachy Paterson, 'Government, Church and Māori Responses to Mākutu (Sorcery) in New Zealand in the Nineteenth and Early Twentieth Centuries', Cultural and Social History, 8, 2 (2011), pp.175-94.

64 Alan Ward, 'Davis, Charles Oliver', Dictionary of New Zealand Biography. Te Ara - the Encyclopedia of New Zealand, updated 1-Sep-10, http://www.TeAra.govt.nz /en/biographies/1d3/1.

65 Woon to Bunting, 26 July 1836, Woon Letters, WMS Papers.

66 Ibid.

67 Woon to Beecham, 3 January 1837, Woon Letters, WMS Papers.

68 Peter Burke, The Art of Conversation, Cambridge, 1993, p.27.

69 Leigh to Marsden, 4 April 1822, MCNZ.

70 Auckland Star, 29 November 1875, p.2. A much shorter funeral notice was placed in the DSC, 29 November 1875, p.2. Complimentary obituaries can be found in the DSC, 26 November 1875, p.2 and Auckland Star, 26 November 1875, p.2. 